\title{
Effectiveness the Use of Audio Visual Media in Teaching Islamic Religious Education
}

\author{
Winarto Winarto ${ }^{1 *}$ Ahmad Syahid ${ }^{2}$, and Fatimah Saguni ${ }^{3}$ \\ ${ }^{1}$ Islamic Education Department, Postgraduate, Institut Agama Islam Negeri Palu \\ ${ }^{2}$ Islamic Education Department, Postgraduate, Institut Agama Islam Negeri Palu \\ ${ }^{3}$ Islamic Education Department, Postgraduate, Institut Agama Islam Negeri Palu
}

\section{ABSTRACT}

This study examines the effectiveness of using audio visual as media in improving learning achievement of a Islamic Junior high schools. The study used qualitative methods with observation, interview and documentation as techniques for data collection. The results of this research shows that the use of audio visual media in enhancing the learning achievement of Islamic education at SMP Negeri 1 Palu was effective for several reasons: First, the use of audio-visual media can clarify the material that is taught, effectifying and functioning students' sensory, both senses of sight and hearing in accordance with the nature of the characteristics of the material and subject matter that is taught. Second, gives stimulation, experiences and observations that is similar to students in the same time with the subject matter. Third, encourages students to be active in learning activity. By using the audio-visual media, we can also say that the PAI teachers have motivated the whole class to be actively included in the teaching learning proces. Fourth, audio-visual media is very effective in improving students' interest and achievement in learning Islamic education. The supporting factors are the learning system thatt is used, the quality of teachers, the facilities and infrastructures, as well as the role of parents, communities and the agencies related. The factors that inhibit the effectiveness of using audio visual media are as follows: (1). Time allocation of learning, (2). Procurement of electricity. To overcome these problems we can use genset macine as temporary power, desain the material an media in accodane with time.

\section{ARTICLE \\ INFORMATION}

\section{Keywords:}

Audio visual, teaching, Islamic education, efectiveness 


\section{Pendahuluan}

Learning is the same as the process of communication or delivery of messages from the teacher to students. The message or information can be in the form of knowledge, expertise, ideas, experience, history, and so on. The achievement of the message conveyed by the teacher to students depends on how the learning process takes place. If learning is carried out effectively, then students will be able to absorb the knowledge and messages that the teacher conveys.

Meanwhile, the teacher is one of the human element in the education process. In the education process in schools, teachers have a dual-task that is as a teacher and educator. As a teacher, the teacher is tasked with pouring a number of learning materials into students' brains. In contrast, as an educator, the teacher is tasked with guiding and fostering students to become capable, active, creative, independent, and innovative human beings. Teaching and educating is a very big task and responsibility as a professional. Therefore, the hard task of a teacher basically can only be carried out by teachers who have high professional competence.

The presence of teachers in teaching and learning is a component that plays an important and major role. That is because teacher factors largely determine the success of the teaching and learning process. Professionalism and teacher skills will significantly affect the results of teaching and learning activities. So it can be said that the task of a teacher is to deliver the subject matter to students through interaction and communication in the teaching and learning process that they do. ${ }^{1}$

The next component is the presence of students in the teaching and learning process. Students are people who learn in social interaction in the form of teaching and learning process. What is meant by learning is a complex process that occurs in every person throughout his life. The learning process occurs because of the interaction between a person and his environment. Therefore, learning can happen anytime and anywhere. One sign that a person is learning is a change in behavior that might be caused by a change in the level of knowledge, skills, and attitudes. ${ }^{2}$

Technology and media can play a lot in learning. If the teacher is teachercentered, technology and media are used to support the presentation of teaching. On the other hand, if teaching is student-centered, students are the main users of technology and media. ${ }^{3}$ Technology plays an important role in the education of students who have specificity. Technology and media that are tailored and specifically designed can contribute to effective teaching from all students and can help them achieve their innate abilities. ${ }^{4}$

1 Basyaruddin Usman dan Asnawir, Media Pembelajaran (Jakarta: Ciputat Pers, 2002), 1.

2 Azhar Arsyad, Media Pembelajaran (Jakarta: Raja Grafindo Persada, 2008), 1.

3 Sharon E.Samaldino, Deborah L.Lowther dan James D.Russel, Instructional Techcnology dan Media For Learning, Terj. Arif Rahman, Teknologi Pembelajaran dan Media Untuk Belajar (Cet. 3; Jakarta: 2014), 14.

4 Ibid., 5. 
In order for learning interactions to run effectively and efficiently, a teacher needs to use the right media. The intended accuracy depends on the learning objectives, messages, or learning the content and characteristics of students involved in learning activities.

Active learning will not run well without enriching learning resources, including messages, people, materials, tools, techniques, and environments that can influence students' learning process and outcomes. Thus, active learning requires the support of facilities outside of humans that can help the learning process of students. Among these facilities are materials provided by the teacher in the form of printed materials or digital materials provided in the computer. In other words, active learning requires media support that can deliver learners' acceleration to the learning material they are learning.

The development of science and technology has brought about changes in almost all aspects of human life in the realm of education. Changes in addition to bringing benefits to human life, on one side of the changes also bring people to an increasingly stringent global era. Therefore, to be able to play a role in global competition, teachers must strive to develop and improve the quality of human resources. Improving the quality of human resources is a reality that must be planned, directed, and efficient in the development process. ${ }^{5}$

5 Abdul kadir, Dasar- Dasar Pendidikan (Cet. 2; Jakarta: Prenada Media Group, 2014), 270.
The purpose of educating the Indonesian people as stated in the Republic of Indonesia Law No. 20 of 2003 "develops the ability and shape the character and civilization of a dignified nation in order to develop the life of the nation, aims to develop the potential of students to become human beings who believe in and fear God Almighty, noble, knowledgeable, capable, creative, independent and become citizens who are democratic and responsible. ${ }^{6}$

The use of media can make teaching and learning processes more practical and efficient. In addition, the difficulty of a teacher in delivering material is more or reduced by the presence of the media. Because teaching and learning activities the obscurity of a material can be helped by presenting the media as an intermediary. The complexity of teaching materials can also be simplified through media tools. That way, students will more easily digest and understand the material presented.

Learning by utilizing media also makes the material more interesting because media learning materials can be delivered in the form of visual and audiovisual. Adding visuals to learning can increase memory from $14 \%$ to $38 \% .7$ The study also showed improvements of up to $200 \%$ when vocabulary was taught using visual tools. The time spent adding verbal results to a picture may not be worth thousands of words, but three times more effective than just

\footnotetext{
${ }^{6}$ Ibid., 271.

7 Mel Silberman, Active Learning (101

Strategi Pembelajaran Aktif), (Yogyakarta: Yappendis,2002), 3.
} 
words

Various types of learning media, such as worksheets, textbooks, and modules, have been commonly used. In addition, now also developing audiovisual media such as video learning, Macromedia, and PowerPoint, to those who utilize the internet network for e-learning. Audiovisual media often used in SMP Negeri 1 Palu is film and video because the media can be played with the help of hardware and software.

Live video or images, are images in a frame where frame by frame is projected through the projector lens mechanically so that the screen looks alive. These media are generally used for entertainment, documentation, and education purposes. Videos and films used in the classroom are learning videos, not merely as entertainment. Videos and films are naturally used in the classroom because they provide facts and answer problems and be able to understand the material to be learned.

Based on preliminary observations of research in SMP Negeri 1 Palu, using audiovisual media increases motivation and learning outcomes of Islamic religious education. The author found that in the learning process of PAI when using audiovisual media, students tend to be enthusiastic about following it because they can see examples of what they are learning directly and can add to their experience in learning. Therefore, researchers are very interested in conducting research in these locations with the aim to find out what audiovisual media is used and how the effectiveness of audiovisual media is related to student learning outcomes.

The possibility of low learning motivation can also be influenced by the use of teacher center learning methods that tend to be monotonous so that some students do not pay attention to the teacher teaching when the lesson is taking place. The lack of use of instructional media as a tool in conveying subject matter content causes low learning interest. Therefore, in overcoming these problems, the learning process requires the help of audiovisual media because audiovisual media is one of the right media to help in overcoming teacher difficulties in explaining material that is abstract and requires direct examples.

In the learning process, a strategy for students' learning should be taken in the form of using audiovisual based learning media. Through audiovisual media, it is expected that the senses of sight and hearing play a full role in capturing all learning information. It can also learn students so that concentration in the learning process is more focused and strives to achieve maximum results.

\section{Literature Review}

\subsection{Learning Media Concepts}

The word media comes from Latin and is a plural form of the word "medium," which means "intermediary" that is the intermediary source of the message (a source) with the recipient of the message (a receiver). ${ }^{8}$ In Arabic, the word media (wasaa ila) means an intermediary or delivery message from

\footnotetext{
${ }^{8}$ Rusman, Belajar dan Pembelajaran e-ISSN: $2715-4572$ p-ISSN: 2716-1439
} 
the sender to the recipient of the message. ${ }^{9}$ Gerlach and Ely say that the media, when understood in broad outline, are humans, material, or events that establish conditions that enable students to obtain knowledge, skills, or attitudes. ${ }^{10}$ In this sense, teachers, textbooks, and the school environment are media. More specifically, the notion of media in the teaching and learning process tends to be interpreted as graphic, photographic, or electronic tools for capturing, processing, and rearranging visual or verbal information. ${ }^{11}$

Many restrictions are given by experts about the media. Among those stated by the Association of Education and Communication Technology (AECT) in America, limiting media as all forms and channels that people use to channel messages/information. ${ }^{12}$ The same was stated by Briggs, who stated that the media are all physical forms that

9 Ahmad Syahid, Rancangan Pembelajaran Model Elaborasi (Cet.2; Jember, Sains, 2008), 160161.

10 Azhar Arsyad, Media Pembelajaran (Cet. 17; Jakarta: Rajawali Pers, 2014), 3.

11 Evita, E., Syahid, A., \& Nurdin, N. (2019). Understanding Students' Learning Outcomes Differences Through the Application of the Market Place Activity Type of Cooperative Learning Model and the Application of Conventional Learning Models International Journal of Contemporary Islamic Education, 1(1), 6785.

12 Arief S Sadiman, Media Pendidikan:Pengertian, Pengertian, dan Pemanfaatanya (Jakarta: PT Raja Grafindo Persada, 2007), 6 . can convey messages and can stimulate students to learn. ${ }^{13}$

Heinich in Ahmad Syahid put forward the term medium as an intermediary that delivers information between source and receiver. Television, films, photographs, radio, radio recordings, projected images, printed materials, and the like are communication media. If the media carries messages or information that aims to learn or contain learning purposes, then the media is called learning media. ${ }^{14}$

From the limitations that have been submitted by experts regarding the media, it can be concluded that the notion of media in learning is all forms of communication tools. That can be used to convey information from sources of students who aim to stimulate them to participate in learning activities.

\subsection{Understanding Learning Media}

Learning media is a messenger technology that can be used for learning purposes. What is meant here is the person/teacher, materials, tools, or events that can create conditions that enable students to receive knowledge, skills, and attitude changes.

According to Miarso, learning media is everything that is used to channel messages and can stimulate thoughts, feelings, attention, and the willingness of students to encourage the

13 Hamzah B Uno, Profesi Kependidikan (Cet. 10; Jakarta: Bumi Aksara, 2014), 114. 14Syahid, Rancangan Pembelajaran, 161. e-ISSN: 2715-4572 p-ISSN: 2716-1439 
learning process that is intentional, purposeful, and controlled. ${ }^{15}$

This learning media is one component of learning that has a very important role in supporting success in the learning process. So the conclusion is learning media are things that can be used to convey messages or information in the teaching and learning process to stimulate the attention and interest of students in learning. The use of instructional media in the teaching and learning process can arouse new desires and interests, generate motivation and stimulation of learning activities, and even bring psychological influences on students.

\subsection{Types of Learning Media}

Learning media have many types and kinds, from the simplest and cheapest to the most sophisticated and expensive. Some of them can be made by teachers themselves, and factories produce some. Some are already available in the environment for immediate use, and some are deliberately designed. The main characteristics of the media are three main elements, which are: sound, visual, and motion.

Judging from this type of learning media can be divided into:

1. Auditive media only rely on the power of sound alone, such as cassette recorders and audio dishes.

This media is suitable for people who are deaf or have a hearing loss

15 Rusman, Deni Kurniawan dan Cepi Riyana, Pembelajaran Berbasis Teknologi Informasi dan komunikasi (Cet. 3; Jakarta: PT Raja Grafindo Persada, 2013), 170.
2. Visual media is media that only relies on the sense of sight. This visual media that displays still images such as film strips (film frames) photos, pictures or paintings, and prints. And there are also visual media that display moving images or symbols such as silent films, cartoons, and so on.

3. Audio-visual media are media that have sound elements and picture elements with various variations. ${ }^{16}$

According to Yudhi Munadi the media in the learning process can be grouped into four major groups, namely:

1. Visual media are media that involve the sense of sight. Through this media, the learning experience experienced by students is very dependent on their ability to see.

2. Audio media is the message to be conveyed poured into auditive symbols, both verbal (into words/spoken language) and nonverbal.

3. Audio-visual media is a media channeling messages by utilizing the sense of hearing and sight.

4. Multimedia is a media that can involve many senses and organs during the learning process. ${ }^{17}$

\subsection{Learning Media Functions}

Learning media has a very strategic function in learning. That is because many students do not

16 Abuddin Nata, Perspektif Islam Tentang Strategi Pembelajaran (Cet. 3; Jakarta: Kencana, 2014), 300.

17 Yudi Munadi, Media Pembelajaran (Jakarta: GP Press Group, 2013), 54.

e-ISSN: $2715-4572$

p-ISSN: 2716-1439 
understand the subject matter delivered by teachers or the formation of competencies given to students due to the absence or lack of optimal learning media empowerment in the teaching process. The functions of media in learning include:

1. As a tool in the learning process. Learning media is a tool that can clarify, facilitate, accelerate the delivery of messages or learning materials to students so that the core of the whole lesson material can be conveyed to students.

2. As a component of the learning subsystem. Learning is a system in which has sub-components, including components of learning media. Thus, the media is a subcomponent that can determine the success of the process and learning outcomes.

3. As a director in learning. One function of the learning media is to direct the message or material to be delivered, or what competencies will be developed for students to have.

4. As a game or to motivate and give attention. Learning media can increase student attention and motivation in learning because learning media can accommodate all student skills in learning. Learning media can provide understanding assistance to students who lack the ability to hear, see, or lack concentration in learning.

5. Improve learning outcomes and processes. In quality and quantity of instructional media greatly contributes to the results and the learning process. Therefore, in the use of media learning must pay attention to the signs of learning media mechanisms.

6. Reducing the occurrence of verbalism. In learning verbalism, it often occurs because what is explained or explained by teachers is more abstract, or there is no form. There are no real illustrations or examples, so students can only say but do not understand the shape, form, or characteristics of objects. Thus learning media can function as an effective tool in clarifying the message delivered.

7. Overcoming the limitations of space, time, energy, and sense power. It often happens in learning to explain learning objects that are very broad, large, or narrow, small, or dangerous, so they need tools to explain and get closer to the object in question. ${ }^{18}$

The use of media at the learning orientation stage will greatly help the effectiveness of the learning process and delivery of messages or content at the time. In addition to arousing students' motivation and interest, learning media can also help students improve understanding, present data attractively and reliably, facilitate data interpretation, and condense information.

\subsection{Definition of Audio Visual Media}

At the beginning of the history of learning, the media is only a tool used

$\begin{array}{ll}18 \text { Rusman, } & \text { Pembelajaran Berbasis } \\ \text { Teknologi, 176. } & \text { e-ISSN: 2715-4572 } \\ & \text { p-ISSN: 2716-1439 }\end{array}$


by the teacher to deliver lessons. In contrast to the present time, the presence of learning media can also provide encouragement, stimulus, and the development of students' intellectual and emotional aspects.

The word audiovisual is a compound word derived from English. Audio means the reception of hearing sounds, 19 and visually, which can be seen in a visible way or can be witnessed. ${ }^{20}$ So it can be concluded that audiovisual can be interpreted as something that can be heard and can be seen at the same time.

According to Sukiman, audiovisual media is a media for message distribution. It utilizes the senses of hearing and sight. ${ }^{21}$ While Yudi Munadi agreed, audio-visual media are media that involve the senses of hearing and vision at the same time in one process. ${ }^{22}$

Ahmad Rohani stated that the audiovisual media was interpreted as a modern instructional media that was in accordance with the times (advances in science and technology), including media that could be seen, heard, and seen heard. ${ }^{23}$ Meanwhile, Wina Sanjaya stated that audiovisual media is a type of media that, in addition to containing sound elements, also contains elements of images that can be seen. For example

19 Yan Peterson, Kamus Lengkap InggrisIndonesia, Indonesia-Inggris (Surabaya: Karya Agung, 2005), 32.

20 Ibid., 390.

21 Sukiman, Pengembangan Media Pembelajaran (Yogyakarta: Pedagogia, 2012), 184. 22 Yudi Munadi, Media Pembelajaran, 56.

23 Ahmad Rohani, Media Instruksiaonal Edukatif (Jakarta: Rineka Cipta, 1997), 97. video recordings, various film recordings, sound slides, and so on. ${ }^{24}$

Based on the understanding above, the audiovisual learning media can be interpreted as a tool that can be seen as well as listened to in the form of video recordings, various film recordings, sound slides, etc. In the teaching and learning process so that the learning material delivered can be well received by students. In line with this, Ngainun Naim explained at length about audiovisual learning media, as follows:

Audiovisual media is a means or a whole media to collaborate with visual forms of audio. This media can be used to help the teacher explain as a confirmation, as an introduction, or as a tool that is explored. This media is not only developed through the form of film alone but can be developed through computer facilities with PowerPoint and flash player techniques. To run this media requires special skills and facilities. ${ }^{25}$

In general, it can be concluded that the audiovisual learning media can be interpreted as a means or medium that combines the form of sound and moving images used to help the delivery of learning material delivered by the teacher so that students can receive it well.

\subsection{Types of Media Audio Visual}

Audiovisual motion media are modern instructional media that are in

\footnotetext{
24 Wina Sanjaya, Strategi Pembelajaran (Jakarta: Kencana, 2007), 172.

${ }_{25}$ Ngainun Naim, Menjadi Guru Inspiratif (Yogyakarta: Pustaka Pelajar, 2009), 224.

e-ISSN: 2715-4572

p-ISSN: 2716-1439
} 
accordance with the times (advances in science and technology) because they include vision, hearing, and movement, as well as displaying elements of moving images. The types of media included in this group are television, videotapes, and motion films. ${ }^{26}$

a) Film

Film or live images are images in a frame where frame by frame is projected through the projector lens mechanically so that the screen looks alive. The film's ability to paint vivid images and sounds gives it its own charm. Both types of media are generally used for entertainment, documentation, and education purposes. They can present information, explain the process, explain complicated concepts, teach skills, shorten or extend time, and influence attitudes. ${ }^{27}$ As for good films, these characteristics are as follows:

1. Can attract children's interests

2. True and authentic

3. Up to date in settings, clothing, and environment

4. In accordance with the level of maturity of the audience

5 . The vocabulary used correctly

6. Its unity and sequence are quite organized

7. The technique used is sufficient to meet the requirements and quite satisfying. ${ }^{28}$

b) Video

26 Nana Sudjana, Media Pengajaran (Surabaya: Pustaka Dua, 1978), 192.

${ }^{27}$ Azhar Arsyad, Media Pembelajaran, 48.

${ }^{28}$ Basyiruddin Usman, Media Pembelajaran,, 95-96.
Video is an audiovisual media, which displays motion, is increasingly popular in our society. The message presented can be fact (important events/news, news), or fictitious (such as stories), informative, educative, or instructional. Most film assignments can be replaced by video, but that does not mean that the video will replace the film's position. Each has its limitations and strengths.

c) Television

Television is an electronic system that transmits still images and live images along with sound through cable and space.

Nowadays, television, which is utilized for educational purposes, can easily be reached via broadcast from air to air and can be connected via satellite. Educational television is the use of planned video programs to achieve certain teaching objectives without seeing who is broadcasting them. Educational television is not only entertaining but more important is educating.

1) Silent Audiovisual Media

a) Sound slides

A-frame film is a transparent (35 $\mathrm{mm}$ ) transparent film, which is usually wrapped in a $2 \times 2$ inch frame made of keraton or plastic. There are programs that finish in one minute, but some are up to an hour or more. But what is common, a sound frame movie program ranges from 10-30 minutes. The number of images (frames) in one program varies, there are only ten pieces, but there are also up to 160 pieces or more. ${ }^{29}$

${ }^{29}$ Arif Sadiman, Media Pembelajaran, 57. e-ISSN: $2715-4572$ p-ISSN: 2716-1439 
b) Movie sound chain

Unlike the film frame, the picture (frame) on sequential sequence film is one unit. The size is the same as the film frame, which is $35 \mathrm{~mm}$. The number of images in one roll of film series ranges from 50 to 75 images with a length of approximately 100 to 130 , depending on the film's contents .30

\section{Methodology}

This study uses a qualitative approach with the object of research is SMP Negeri 1 Palu. The author chose this school as the location of the study because the school is one of the junior high schools in the ICT-based learning process. In addition, because this school is a school that has outstanding achievements in the field of education, both at the local and national level.

Using qualitative methods in this study with several considerations. ${ }^{31}$ First, adjusting qualitative methods is easier when dealing with multiple realities. Second, it can present the nature of the relationship between researchers and informants directly. ${ }^{32}$ Third, this method is more sensitive and adaptable to the many sharpening of

30 Ibid., 61.

31 Nurdin. (2014, 28-30 May 2014). Understanding government e-procurement effectiveness from users' perspectives: A case of social media discussion in Indonesia local government. Information and Communication Technology (ICoICT), 2014

32 Nurdin, N. (2017a). Research in Online Space: The Use of Social Media for Research Setting Jurnal Sistem Informasi (Journal of Information System), 13(1), 67-77. shared directors and the patterns of values encountered. 33

Data were collected using observation techniques, in-depth interviews, and studies from various written documents. ${ }^{34}$ While data analysis was carried out using reduction and verification techniques with various data sources. ${ }^{35}$ The reduced data then analyzed by claiming the theoretical concepts used in this study.

\section{Result and Discussion}

\subsection{Use of Audio-Visual Media}

The use of computers as learning media is a new thing for some schools. Still, for SMP Negeri 1 Palu, the use of computers is necessary to improve the quality of learning meant learning outcomes/student learning achievements. Quality learning needs to be realized in order to obtain quality human resources (HR) that can meet the needs and challenges of a society in this globalization era. In the pedagogical aspect, the use of media and information technology in education is one part that can not be avoided and is expected to be an alternative problem-solving in learning PAI.

${ }^{33}$ Ibid., 5.

34 Nurdin, N. (2017b). To Research Online or Not to Research Online: Using Internet-Based Research in Islamic Studies Context. Indonesian Journal of Islam and Muslim Societies, 7(1), 31-54.

35 Nurdin, N. (2016). The Roles of Information Technology in Islamic Bank Knowledge Management: A study of Two Syariah Banks in Palu. Hunafa: Jurnal Studia Islamika, 13(2), 181-217.

e-ISSN: 2715-4572

p-ISSN: 2716-1439 
Information and technologybased learning could be utilized by teachers in schools. One of the technology products considered appropriate to be used to improve effectiveness in the learning process is a learning program using computer assistance or CAI (Computer Assisted Instruction). In the CAI (Computer Assisted Instruction) program, computer equipment is used as a means to develop and operate learning media that can help students and teachers understand a concept, formulate, and practice it.

The teacher's role in the learning process greatly determines the level of success in learning because the teacher is directly fostering, guiding, and directing students in the classroom and outside the classroom. Therefore, efforts to improve the quality of education must be made by teachers in carrying out their duties and responsibilities as educators.

Efforts to improve the quality of education in question are none other than the ability of teachers in general and, particularly, teachers in the field of Islamic religious education studies in preparing learning material, as well as selecting media suitable for learning material. It is intended to improve the quality of student learning outcomes. The learning media functions to stimulate learning motivation, repeat what has been learned, provide learning stimulus, activate students' responses, and provide immediate feedback.

The preparation of Islamic religious education material in SMP Negeri 1 Palu uses a program called Microsoft PowerPoint, modified in the form of video, animation, or other so that it can be displayed on a Projector slide is well designed, interesting, concise and clear. Because the media functions to simplify the material that is difficult to understand, it becomes easier to convey, if used properly, to improve the quality of student learning outcomes because the material delivered is much more concrete. ${ }^{36}$

Based on the above interview results from it can be explained that the preparation of Islamic religious education subject material in SMP Negeri 1 Palu uses one program called Microsoft PowerPoint. It is modified into the form of videos, short films, animations, or in other forms so that it can be displayed on slides A welldesigned, attractive, concise, and clear projector or infocus. This is made clear by the following quotation from an interview with Mr. Mohamad Din: In the use of media, there are several things that must be considered by each teacher in designing learning objectives, compiling learning materials, choosing learning methods, the availability of tools used in learning, knowing the interests of students, and understanding the situation of the class when learning takes place. ${ }^{37}$

Based on the results of the interview above, it can be explained that when a teacher will use the media in the learning process should pay attention to

${ }^{36}$ Emi Indra, Guru Pendidikan Agama Islam SMP Negeri 1 Palu, "wawancara" di Ruang Guru pada tanggal 17 Juli 2017.

37 Mohamad Din, Pendidikan Agama Islam SMP Negeri 1 Palu, "wawancara" di Ruang Guru pada tanggal 26 Juli 2017. 
several things, including the learning objectives to be achieved, the learning methods to be used, and the availability of tools to be used. From the results of the informant's explanation above, it can be seen that the audiovisual learning media, however good and sophisticated. But cannot be utilized maximally, the audiovisual learning media cannot help improve the quality of student learning outcomes, meaning it is very ineffective. That is why the preparation of subject matter is getting more attention because if it is made interestingly, then the interests and motivations of students in responding or listening to the material are more optimal.

Audiovisual media that is used must have its meaning for Islamic teachers who use it so that the teacher can help the students process the educational messages they convey. This is consistent with the results of an interview with one of the Islamic religion teachers.

Every teacher in Palu 1 they get professional guidance and other competencies with an activity called the teacher's deliberations (MGMP), both in the environment of the Palu SMP 1 teachers themselves, as well as at the city level and even at the national level. It is honed and developed so that it becomes a professional teacher in preparing subject matter that will be presented to students. 66Audio visual media that is used must have its own meaning for Islamic teachers who use it to help his students, process the educational messages they convey. It is consistent with the results of an interview with one of the Islamic religion teachers.
Every teacher in Palu 1 they get professional guidance and other competencies with an activity called the teacher's deliberations (MGMP), both in the environment of the Palu SMP 1 teachers themselves, as well as at the city level and even at the national level. It is honed and developed so that it becomes a professional teacher in preparing subject matter that will be presented to students. ${ }^{38}$

This is reinforced based on the results of observations by researchers at the research location as follows:

Each current period is usually the beginning of the year PAI subject teachers in the city of Palu get professional development in the theme of ICT-based learning in developing and using learning media because PAI teachers must master technology because technology has entered everyday life by which teachers, especially PAI teachers, cannot be biased avoid from technology-based media learning. ${ }^{39}$

Based on the results of the interview above, the researcher concludes that teachers at SMP Negeri 1 Palu already have good competence in their respective fields. Both in the preparation or in terms of designing learning and intended in using models, strategies, and teaching methods that are appropriate to the material to be taught to students. As explained by the head of the SMP Negeri 1, every year, teachers

${ }^{38}$ Hardi, Kepala SMP Negeri 1 Palu, "wawancara" di Ruang Kepsek pada tanggal 28 Juli 2017.

39 Lihat Transkrip Dokumen, No 01, Tentang Tenaga Pendidik, h,122.

e-ISSN: 2715-4572

p-ISSN: 2716-1439 
who are at SMP 1 Palu are given guidance and training to become qualified professional educators/teachers.

The use of audiovisual media in Islamic religious education learning will attract more students' attention, students will easily understand learning materials, teaching methods will be more varied, and students will do more learning activities. Even the use of audio-visual media can improve the quality of the process and learning achievement, from concrete thinking to abstract thinking. ${ }^{40}$

The explanation from the interview results above illustrates that the audiovisual media in the learning process does not only have an additional function, but the audiovisual media has its function as a tool to realize an effective learning situation. This means that audiovisual media is one of the most important elements in the learning process that must be developed by every teacher. The use of audiovisual media can improve the quality of the learning process so that students' achievement or learning outcomes can increase. Through computer media, a teacher can present messages or material through the senses of hearing and vision so that it can help teachers accelerate the learning process and help students in their efforts to understand the subject matter presented by the teacher.

The audiovisual media that is often used by Islamic religious teachers in SMP Negeri 1 Palu in the learning

40 Emi Indra, Guru Pendidikan Agama Islam SMP Negeri 1 Palu, "wawancara” di Ruang Guru pada tanggal 17 Juli 2017. process. The media such as videos about education, animation film screenings, using computer or laptop aids that are presented through infocus highlighted in front of the writing pad or classroom wall. So that students as a whole can clearly see the material being taught.

As the results of interviews with PAI teachers who stated that the media that I often use in teaching is like playing educational videos related to the material that I will teach that day. Such as videos of faith, in the end, videos about filial piety to parents, and other videos related to the material.

Based on the results of the interview above, it can be seen that the media that are often used by Islamic religious teachers in SMP Negeri 1 Palu are like video-education, as well as media by using Microsoft PowerPoint to explain the material to be taught to students.

This is consistent with the observations of researchers in the field, which show that the way teachers use instructional media in the teaching and learning process is very skilled so that it is quite effective in delivering Islamic religious education subject matter. As for the media such as videos about education, the screening of animated films, using a computer, or a laptop's help that are presented through infocus highlighted in front of the writing board or classroom wall.

The tendency of learning with integrated computer media emphasizes the integration of various competencies to be achieved with the learning experience through vision, hearing, and movement that can facilitate the 
achievement of learning goals. Learning with a computer and an LCD projector will provide an opportunity for students to get authentic learning materials and can interact more broadly.

The more precise the way it is presented, the easier it is for students to understand the teacher's material. The presentation of sophisticated visual media certainly requires quite a lot of funds, so not all educational institutions can provide that media. The provision of visual media such as LCD projectors must be adjusted to the ability of the school or madrasah, such as in SMP Negeri 1 Palu.

Audiovisual learning media in SMP Negeri 1 Palu, almost all classes have LCD projectors, which are often used by teachers in presenting material through video shows or the like. The strategy used in learning Islamic religious education is a strategy of observing or criticizing videos called a strategy to criticize videos. In this strategy, students are asked to observe or respond to the video that has just been played. Critical video categories are used to train students to be more critical in responding to phonemes occurring in the community. With this strategy, students are expected to be able to understand the subject matter of Islamic religious education easily.

The strategy to watch video shows in Islamic religious education learning is as follows:

a. The teacher opens the lesson by giving a greeting.

b. The teacher agrees to the students that today's material on believing in the Day of Judgment in the form of video will be played through the LCD projector or infocus.

c. The teacher divides students into several teams or small groups

d. Before the video is played, the teacher asks each group to listen and pay attention to the video about the doomsday. Then the teacher allows each group or team the opportunity to respond and criticize the video.

e. The next step is evaluation before the lesson closes the teacher clarifies the video about faith again to the Day of Resurrection. The teacher closes the lesson by reading hamdallah and greetings.

There are several things that must be considered in developing material or messages that will be presented in learning so that it is not verbalism, which is presented in the form of words or writing.

The learning done by the teacher by using audiovisual learning media is adjusted to the material to be taught so that students are more interested and easy to understand what the teacher is conveying. This is justified by Melviana and Triyogo Jati Prasojo. P students of SMP Negeri 1 Palu in the interview stated as follows:

As students, we better understand every material of Islamic religious education taught through audiovisual media. The discussion becomes more concrete. Besides that, it is also very interesting and clear, so that we more easily

e-ISSN: 2715-4572

p-ISSN: 2716-1439 
understand and appreciate the material. ${ }^{41}$

In every Islamic religious education learning that uses audiovisual media, we are very enthusiastic to follow it because the material presented is clearer and more concrete. It is accompanied by concrete examples so that we more easily understand the material being taught. ${ }^{42}$

Based on the explanation from the two informants above, it can be concluded that they prefer and more easily understand the subject matter of Islamic religious education taught by using audiovisual learning media. Besides being easier to absorb and understand, they are also very enthusiastic about following the learning process because they are not easily bored, and they always want to learn that is interesting and exciting.

This was made clear by Ms. Aisyah as a teacher of Islamic education at SMP Negeri 1 Palu stating that:

A good learning process must be experienced directly by students. Therefore I try to present these facts through learning media. In this school, all classes have infocus installed, so I use various video recordings regarding the subject matter as learning media. The students' response is also very attentive and very enthusiastic in

${ }^{41}$ Melvina, Peserta didik SMP Negeri 1 Palu, "wawancara" di Ruang Kelas, tanggal 25 Juli 2017.

42 Triyogo Jati Prasojo.P, Peserta didik SMP Negeri 1 Palu, "wawancara" di Ruang Kelas, tanggal 25 Juli 2017. paying attention to the subject matter during the learning process in class. ${ }^{43}$

Based on the results of the interview above, it can be explained that the quality of the learning process is good and that students should be directly involved in the learning process. Therefore, in an effort to attract students' interest and attention in learning, teachers should always try to provide meaningful and enjoyable learning through audio-visual learning media.

2). The Ability of Students in Receiving Learning Materials

One component that determines students' ability to receive subject matter is the existence of good interaction and communication between teachers and students. Based on the researchers' observations at the research location, which shows the attitude of students in accepting subject matter that uses audiovisual media in the learning process very well. It is made clear by the statement of Islamic education teachers of SMP Negeri 1 Palu, that:

The use of media in the learning process, such as audiovisual media is very helpful in the effectiveness of the learning process and the delivery of material. Children will be more motivated and more quickly understand the learning material. This is because, through the audiovisual media, the material is presented more attractively and

43 Aisyah, Guru Pendidikan Agama Islam SMP Negeri 1 Palu, "wawancara" di Ruang Guru pada tanggal 17 Juli 2017.

e-ISSN: 2715-4572

p-ISSN: 2716-1439 
directs children to concentrate more on the contents of the learning material. In fact, they are very enthusiastic and enthusiastic in following the subject matter to the end. ${ }^{4}$

The explanation above is clear that by using audiovisual media, the students' interest and enthusiasm for learning in receiving Islamic religious education subject matter are very good. This is because, with audiovisual media, the learning process will be more enjoyable. Students will be easier to understand the explanation of the material because they can see direct examples of the material being learned in real life.

\subsection{Effectiveness of Using Audio Visual Media}

The modern education system functions as a teacher to convey educational messages that need to be assisted with learning media so that the learning process can take place effectively. This is because the teacher's job is a professional job that requires ability and authority

Learning that takes place in schools and madrasah is now growing. Starting from the traditional teaching process with conservative characteristics developing and now modern learning systems, learning has characteristics in accordance with the times. In the stages of development, there are changes that occur in the learning system with all aspects and elements.

44 Mohamad Din, Guru Pendidikan Agama Islam SMP Negeri 1 Palu, "wawancara” di Ruang Guru pada tanggal 26 Juli 2017.
Teacher and student interaction is a component that plays the most important role in the learning process to achieve effective learning goals. Given the position of students as subjects and also as objects in learning, the core of the learning process is nothing but the learning activities of students in achieving a learning goal. Integration between students' learning process with the teacher's teaching process, so that teaching and learning interactions occur. Teaching and learning activities do not come and grow just like that without the proper arrangement and planning of a teacher.

Learning planning as a collaborative process focuses not only on the activities of the teacher or the activities of students, but the teacher and students together try to achieve the specified learning goals. In planning learning, one must also pay attention to the principles that can lead to a goal. Thus, the end result of the learning process will create quality human resources who are skilled and qualified.

Because the success of an activity is largely determined by its planning, learning planning can act as a Reference for teachers to carry out learning activities to be more directed and run efficiently and effectively as a basic foundation for teachers and students in achieving basic competencies and indicators set.

Learning activities occur when the educative interaction process between teachers and students. The activities carried out lead to one goal, which is to achieve predetermined learning objectives.

e-ISSN: $2715-4572$

p-ISSN: 2716-1439 
Based on the two restrictions above, it can be understood that a learning process is a form of activities carried out by the teacher and students by establishing educational communication using certain strategies, approaches, principles, and methods in order to achieve effective and efficient learning objectives based on planning that was made before. Therefore, learning activities must be carried out optimally and adequately so that learning objectives can be achieved optimally and adequately.

The effectiveness of learning can be achieved very depending on teachers' ability to achieve the success of the learning process. In learning at school, there is a learning process, namely the process of changing knowledge, attitudes, information, abilities, and skills that are permanent through experience.

Characteristics of effective learning include seen from the level of student activity in learning. The higher the learning activities of students, the higher the chances of successful learning. In this case, the teacher in learning must be able to motivate students to carry out various learning activities. The following will describe some of the effectiveness of audio-visual media in improving Islamic religious education learning achievement in SMP Negeri 1 Palu.

a. Making the way of learning easy

In educational interactions, activities are usually used tools, both material and non-material. Material tools referred to as audiovisual aids in it. As the results of the researcher's interview with the Islamic religion teacher of SMP Negeri 1 Palu as follows:

The use of audiovisual aids in the educational interaction process is very supportive of the smooth running of learning activities. Because perfect learning can only be achieved if audiovisual materials are used close to the reality of life and the students' experience. Audiovisual media can also reach students as a whole, making it easier for teachers in the learning process. ${ }^{45}$

As the Islamic religious education teacher explained above, the researcher concludes that the use of audiovisual media in the learning process is very important to facilitate the learning process and achieve learning objectives. By using audiovisual media, it can clarify abstract material. To make it easier for teachers or educators to convey material information to students in large numbers.

\section{a. Provide real experience}

Learning supported by learning media, including audiovisual media, can provide real experiences to students in learning. Religious problems, such as the power of Allah swt., can be displayed in the form of videos or films. Suppose the teacher shows or plays a film or video about the solar and lunar eclipse process from the beginning of the eclipse to the end and back until it is bright. This recorded real experience is presented to

45 Emi Indra, Guru Pendidikan Agama Islam SMP Negeri 1 Palu, "wawancara" di Ruang Guru pada tanggal 17 Juli 2017.

e-ISSN: 2715-4572

p-ISSN: 2716-1439 
the students so that the religious messages can be experienced by the students wholeheartedly and convincingly.

Provide the same stimulus, experience, and observation to students at the same time. Using the right audiovisual media will provide the same quality stimulants to students so that the messages and learning material delivered by the teacher will be shared simultaneously throughout the class unless there are among students who are not well equipped with five senses.

Media integration is essential in integrating aspects and skills that must be learned. To attract students' interest in learning a program or material must have artistic value and aesthetic value. The tendency of learning with a computer or laptop program emphasizes the integration of various competencies to be achieved with the learning experience through the sense of sight, and the movement of animation. There are several reasons for using computer or laptop media as a result of the Researcher's interview with Islamic religion teachers:

As learning media, among others, direct experience, can motivate, broader interaction, can enhance authentic learning, not focused on one learning source, provide the global understanding and can increase the focus of student learning, so expect learning will be more effective and efficient. 74

Based on the results of the interview above, it can be seen that the computer or laptop media, especially audiovisual media, is very helpful for teachers and students in carrying out the process of teaching and learning activities. At the time of the learning process, the effectiveness of a learning media can be seen from the level of student activities. The higher the learning activities of students, the higher the chances of learning success. Learning activities can be realized because of the high motivation of students. Motivation is an abstract thing. Therefore the actualization of participants' learning motivation is learning activities.

The rapid development of science and technology lately has had a positive impact on the world of education, especially in SMP Negeri 1 Palu. In the process of learning, this school uses ITbased learning that uses computer media and LCD projectors as one of the learning media. Current technological advances encourage educators or teachers to be more innovative in learning. In order not to be out of date, SMP Negeri 1 Palu chose computer media as a medium of learning technology.

b. Attract the attention and interest of students in learning

Audiovisual media is very effective in attracting attention and interest in the learning process of students. This is because the look is interesting and not boring. Students at the junior high level, really like moving images/animations and have the power of sophisticated technology. This was confirmed by the statement of the Islamic religion teacher at SMP Negeri 1 Palu in the following interview:

e-ISSN: 2715-4572

p-ISSN: 2716-1439 
Students at the junior high level really like things related to technology. This also applies to students in SMP Negeri 1 Palu. They really like it when the learning process is using computer media or using audiovisual media that is interesting because they can follow the explanations of the material given by the teacher in the form of audio and visual simultaneously. ${ }^{46}$

From the explanation above, it can be seen that the use of computers and audiovisual media in the learning process is very effective in attracting the attention and interests of students. Audiovisual media is also very helpful in dealing with students who are lazy and easily bored in attending Islamic religious education lessons due to less varied teaching methods.

c. Facilitate the delivery of abstract material (theory)

In addition to generating motivation and interest of students, learning media (audiovisual) can also help students improve understanding, present data attractively and reliably, facilitate interpretation of data, and condense information.

Audiovisual media has an important role in facilitating students to absorb or accept material that has been delivered by the teacher or educator, especially material that is still abstract.

${ }^{46}$ Emi Indra, Guru Pendidikan Agama Islam SMP Negeri 1 Palu, "wawancara" di Ruang Guru pada tanggal 17 Juli 2017.
And can encourage the desire of students to know more and in-depth about the material or messages conveyed by the teacher or educator. Besides, audiovisual media can also avoid misunderstanding between students with one another, as well as to the material or messages conveyed by the teacher. This is confirmed by the results of an interview with Ms. Emi Indra as a religion teacher at SMP Negeri 1 Palu as follows:

The media or aids in learning are said to be effective if the media can communicate the material or the contents of the material. Teaching messages that will be delivered by the source or teacher to the target to be achieved in this case are students. Audiovisual media can also manipulate an object or data as needed. In addition, the cost factor must also be considered because the cost must be assessed with the results to be achieved by the use of the media itself. The availability of facilities such as electricity, the state of the classroom, the time required, and its effect. Then the more learning objectives that can be assisted with a learning media, the better (effective) the media is. ${ }^{47}$

Based on the explanation above, it can be seen that the effectiveness of a media can provide quality learning. By still paying attention to the availability of facilities such as electricity, the state of the classroom, the time required, and the effect it has. As for learning by using

47 Emi Indra, Guru Pendidikan Agama Islam SMP Negeri 1 Palu, "wawancara" di Ruang Guru pada tanggal 17 Juli 2017.

e-ISSN: 2715-4572

p-ISSN: 2716-1439 
a computer or laptop program and Liquid Crystal Display (LCD) in learning, some things must be considered for assessing interactive media; First of all, ease of navigation, a program must be designed as simple as possible. Second, the content of cognition in the form of knowledge and presentation of information delivered. Both of these criteria are to assess the contents of the program itself, whether the program has met the learning needs of students or not.

\section{d. Learners become more active}

The purpose of choosing computers and audiovisual media as one of the learning media is to produce more active, innovative,, and enjoyable learning. As the interview with the Vice President of facilities and infrastructure as follows:

a. Technology advances. This requires schools to keep pace with technological progress and as a vehicle for innovation in the learning process.

b. Innovation in learning. The variation in the use of this media aims to make students not bored and bored during the learning process. With the innovation of learning, students are more motivated in learning.

c. It is hoped that with the presence of computer media, especially audiovisual media, students will be more active and enthusiastic in attending Islamic religious
education. 48
The opinion above was strengthened by Islamic religious teachers in interviews about the use of computer media (audiovisual), which was quite effective as a medium of learning. This is described at length as follows:

a. Clarify the subject matter presented. The use of audiovisual media can make an effective and functional sense of students both senses of sight and hearing in accordance with the nature of the material, and the subject matter delivered.

b. Help ease the role of PAI teachers. Religious teachers are able to choose audiovisual media that is suitable for the material and program the user, so the role can be left in part to the media concerned so that it indirectly helps to stimulate students involved in the teaching and learning process.

c. Encourage students to learn actively. During the use of audiovisual media indirectly PAI teachers have motivated the entire class to be actively involved in the teaching and learning process. In fact, it is not uncommon for students who want to once again follow and repeat the presentation

${ }^{48}$ Meithy Ningsih, wakasek sarana dan prasarana SMP Negeri 1 Palu, "wawancara" di Ruang wakasek pada tanggal 24 Juli 2017.

e-ISSN: $2715-4572$

p-ISSN: 2716-1439 
because of their great desire to understand the material well. ${ }^{49}$

Implementation is an activity to realize plans into concrete actions in order to achieve effective and efficient learning goals. Supervision and evaluation are a series of efforts to control teachers in a professional manner to function as it should. That way plans to achieve goals can be carried out effectively and efficiently. In each learning after the planning, the next step is to carry out every planning in learning and then in the implementation stage of the learning process. Of course, it can not be separated from the teacher's supervision, and the final step is to evaluate each progress experienced by students.

Having computer media as one of the learning media can clarify the subject matter delivered, help ease the role of PAI teachers, encourage active learners to learn, and provide real experiences to students. It can provide the same stimulation, experience, and observations to students at the same time. It can also attract the attention and focus of students in following the lesson because the material is highlighted on the wall or whiteboard through the infocus or LCD projector. So that learning is more active, classroom conditions are more conducive, learning can be more effective. Good interaction between teachers and students produces a high absorption of the subject matter understanding and has a positive impact on students' psychological.

${ }^{49}$ Emi Indra, Guru Pendidikan Agama Islam SMP Negeri 1 Palu, "wawancara" di Ruang Guru pada tanggal 17 Juli 2017.
Based on the results of the interview revealed by Muh. Abd. Khalik. Bass, as follows:

Various kinds of ways that teachers do so the material delivered to students can be understood; one of them is on Islamic religious education subjects. Islamic religion teachers often use computer media in teaching, so students are easier to understand the material being taught. 50

A similar opinion was expressed by one of the hammer 1 Junior High School students in the interview as follows:

In my experience during the teaching and learning process, using computer media and audiovisual in learning is very interesting. Because the subject will look more entertaining to learn about, also every material presented through the media is mostly associated with events in everyday life around us so that it is more real and easy to understand. 51

Based on the interview results above, it can be seen that the role of computer media is very urgent in improving the active, conducive, and enjoyable learning process. The media also has an impact on good learning outcomes or achievements. Many

50 Muh. Abd. Khalik. Bas, Peserta didik SMP Negeri 1 Palu, "wawancara" di Ruang Kelas, tanggal 25 Juli 2017.

51 Melvina, Peserta didik SMP Negeri 1 Palu, "wawancara" di Ruang Kelas, tanggal 25 Juli 2017.

e-ISSN: 2715-4572

p-ISSN: 2716-1439 
considerations were carried out by Islamic religion teachers in choosing learning media. Computer media is very effectively used as a tool in learning.

Computer media can embed the basic concepts that are true, concrete, and realistic. Islamic religious education teachers do not always use computer media in every delivery of material. The use of computer media is used when the material is difficult to explain, and it is very difficult for students to understand. For this reason, computer media is used to display material in the form of explanations such as pictures or videos relating to material that requires examples so that students can easily know and understand the purpose of the material delivered by Islamic religious teachers.

Media Computer is very effectively used by Islamic religious teachers as learning media because computer media is very efficient in helping to provide explanations for material that is difficult for students to understand, especially abstract material. With computer media, the teacher no longer needs to record the subject matter during class time because this takes up a lot of time that should be used to explain the material and interact even more intensely with students.

Through computer media, the subject matter can be prepared in advance and stored in the form of software that could one day be displayed if needed. This media is very efficient to be used in abbreviating material so that it allows two meetings of material to be completed in one meeting.
The learning objectives are achieved by using computer media. It can be seen from the completion of the subject matter, the active learning atmosphere, the students' absorption of the subject matter, is higher. Students become more enthusiastic and active in learning Islamic religious education. Religious teachers also become more creative in choosing and designing media that will be used in delivering Islamic religious education materials. The use of computer media can increase interest and foster student motivation in learning Islamic religious education lessons. This bias can be illustrated by the focus of students in watching the display on the LCD screen or carefully focusing. This proves that students feel interested and happy to follow Islamic religious education lessons taught through computer media and audiovisual media.

For teachers, it is not easy to master the classroom and create a conducive climate, using students' computers is easily controlled, and a conducive climate can be realized. This is proven by students feeling comfortable in learning, and it is not seen students who are coughing or talking to their peers. Besides that, an active learning atmosphere is created where students are the center of learning, and the teacher acts as a facilitator. The use of computer media makes students ask lots of questions and express opinions. This indicates that students increasingly understand the material delivered by the teacher. Computer media can instill the basic concepts that are true, concrete, and e-ISSN: 2715-4572 p-ISSN: 2716-1439 
realistic, and this can affect the absorption of students with the material presented. Students do not only know the basic concepts but through computer media, students can find out the concrete real fiber reality.

The use of computer media has a positive impact on teacher psychology. Cognitively the teacher gets a lot of information about the progress of the development of instructional technology media. The affective aspect of it is the teacher feels calm when conveying subject matter using a computer that is not overshadowed by the lack of time. Besides that, psychomotor teachers are increasingly skilled in choosing and designing appropriate learning media design material to be delivered. With this positive impact, computer media is effectively used as a learning medium.

Various advantages possessed by computer media, are inseparable from shortcomings, while the shortcomings of computer media are limited funds, to buy or procure a set of computers complete with software and hard fixes, not a small amount of funds must be spent. It makes many schools do not have a set of computers and LCD. Besides the limitations of the technical and theoretical teachers on technology, so that the media is less developed, in addition to the computer media does not function when the electricity is extinguished, so that requires teachers to find and make learning media as a substitute for LCD media.

Before using LCD media, students state that PAI learning seems boring, especially since students must listen to the teacher's lecture, making students uncomfortable in the classroom and want the lesson to finish quickly. This results in students not being motivated to learn and the impact they do not understand the material that has been delivered by the teacher. This is different after using a computer as a source of media. Because media is quite interesting with varied slides so that they are motivated to follow the learning and are more focused and more active, not only are the students more comfortable in the classroom. But also, the classroom's atmosphere is more conducive; this affects their absorption with the material being taught.

Based on the results of observations and interviews conducted by researchers, it can be described some of the effectiveness of the use of audiovisual in the system, including the following:

a. The learning atmosphere becomes conducive and active

b. The absorption of learning material is higher

c. Students are more active in learning

d. Learners are more motivated in learning

e. Students are more focused on following the learning process

$\mathrm{f}$. The teacher becomes more skilled in choosing and designing learning media.

g. Simplify the process of delivering PAI learning materials

Based on what the researcher has found, it can conclude that the role of instructional media is very important in the learning process, including the audiovisual media itself, which is able to make the learning atmosphere become e-ISSN: $2715-4572$ p-ISSN: 2716-1439 
active, conducive and efficient in the delivery of material or teaching material to students. Audiovisual media can help teachers explain the difficult material for students to understand, such as material relating to religious issues that are still abstract. Therefore the media can provide more concrete examples. Audiovisual media can also increase students' interest and motivation to learn so that it is expected that the results or learning achievements of Islamic religious education can increase better.

\section{Conclusions}

Based on the results of the thesis discussion above, the author can conclude several things as follows:

The use of audio-visual media in Islamic religious learning is very effective in the process of delivering subject matter. So the learning outcomes of students can increase. Therefore, teachers are expected to have the ability to design and integrate various types of media into their learning plans. So that the learning process can be carried out and achieve the goals that have been determined.

The effectiveness of audiovisual media in Islamic religious learning is very effective and useful because the material delivered is not merely verbalized. But the delivery of the material can be through computer media, by utilizing various features such as videos and photo slides/images whose nature is very helpful in transferring knowledge to children/students.
The effectiveness of audiovisual media's use can also be seen from the completeness of the subject matter, conducive, and active learning arrangements. Higher students 'absorption capacity, students' motivation that is much more increased, and teachers become more creative in choosing and designing media that will be used in the learning process.

Supporting factors for the use of audio-visual media in the learning process are (1) the learning system used, (2) the quality of educators/teachers, (3) students, (4) existing facilities and infrastructure, (5) the role of parents, surrounding communities and related institutions.

While the inhibiting factors of the use of audiovisual media are (1)The allocation of learning time is only $2 \times 45$ minutes per week. (2)Frequent rotating power outages or even unscheduled outages make learning activities less than optimal. Basically, every obstacle can certainly be found to be a solution so that the learning process can still run well, and the learning process's objectives can be achieved. The purpose of learning itself is expected to lead to the goal of Islamic education, which is in line with the goals of human life itself, namely to form human beings who are always obedient to almighty Allah in every aspect of their lives.

\section{REFERENCES}

Arifin, Imron. Penelitian Kualitatif dalam Ilmu-ilmu Sosial dan Keagamaan. Malang: Kalimasada Press, 2010. 
Arsyad, Azhar. Media Pembelajaran. Cet. 17; Jakarta: Rajawali Pers, 2014.

B Uno, Hamzah. Profesi Kependidikan. Cet. 10; Jakarta: Bumi Aksara, 2014. Bungin, Burhan. Peneiltan Kualitatif, Komunikasi, Ekonomi, Kebijakan Publik, dan Ilmu Sosial lainnya. Edisi. I; Cet. I; (Jakarta: Kencana Prenada Media Group, 2007.

Dariyo, Agoes. Dasar- dasar Pedagogi Modern. Jakarta: PT Indeks Permata Puri Media, 2013.

Daryanto, Media Pembelajaran. Yogyakarta: Gava Media, 2010.

Davies, Ivor K. Pengelolaan Belajar. Jakarta: Rajawali Pers, 1991.

Departemen Agama RI, Al-Qur'an dan Terjemahnya. CV. Karya Utama Surabaya, 2005.

Departemen Pendidikan Nasional, Kamus Besar Bahasa Indonesia. Cet.3; Jakarta, Balai Pustaka, 2003.

Djamarah, Syaiful Bahri, dan Aswan Zain. Strategi Belajar mengajar. jakarta: Rineka Cipta, 2006.

E.Samaldino, Sharon. Deborah L.Lowther dan James D.Russel, Instructional Techcnology dan Media For Learning, Terj. Arif Rahman, Teknologi Pembelajaran dan Media Untuk Belajar. Cet. 3; Jakarta: 2014.

Evita, E., Syahid, A., \& Nurdin, N. (2019). Understanding Students' Learning Outcomes Differences Through the Application of the Market Place Activity Type of Cooperative Learning Model and the Application of Conventional Learning Models International Journal of Contemporary Islamic Education, 1(1), 67-85.
Fathurrohman, Pupuh. dan Sobry Sutikno, Strategi Belajar Mengajar. Cet. 6; Bandung: 2014.

Hamalik, Oemar. Media Pendidikan. Bandung: Alumni, 1985.

Ihsan, Fuad. Dasar- dasar Kependidikan, (Komponen MKDK). Jakarta: Rineka Cipta, 2008.

Irham, Muhammad, dan Novan Ardy Wiyani. Psikologi Pendidikan; Teori dan Proses dalam Proses Pembelajaran. Yogyakarta: Ar-Ruzz Media, 2013.

Iskandar, Metodologi Penelitian Pendidikan dan Sosial. Jakarta: Ikapi, 2013.

Jihad, Asep, dan Abdul Haris. Evaluasi Pembelajaran. Cet. 1; Yogyakarta: Multi Pressindo, 2012.

Kadir, Abdul. Dasar- Dasar Pendidikan. Cet. 2; Jakarta: Prenada Media Group, 2014.

Latipah, Eva. Pengantar Psikologi Pendidikan. Yogyakarta: Pedagogia, 2012.

A. M, Sardiman. Interaksi dan Motivasi Belajar-Mengajar. Cet. 21; Jakarta: Raja Grafindo persada, 2012.

M. Trobroni, Belajar dan Pembelajaran;Teori dan Praktik. Cet.1; Yogyakarta: Ar-ruz Media, 2015.

Mahmud, Metode Penelitian Pendidikan. Bandung: Pustaka Setia, 2011.

Maleong, Lexy J. Metodologi Penelitian Kualitatif. Cet. XVII; Bandung: PT. Remaja Rosdakarya, 2002.

Margono,S. Metode Penelitian Pendidikan. Cet. II; Jakarta: Rineka Cipta, 2000.

Maslikhah, Ensikopedia Pendidikan. Salatiga: STAIN Saltiga Press, 2009.

Milles, Matthew B, dan A. Michael Huberman. Qualitative Data Analisis, diterjemahkan oleh Tjecep e-ISSN: 2715-4572 p-ISSN: 2716-1439 
Rohendi Rohili dengan judul Analisis Data Kualitatif: Buku tentang Metode-metode Baru. Cet. I; Jakarta: UI Pres,2005.

Munadi, Yudi. Media Pembelajaran. Jakarta: GP Press Group, 2013.

Musrofi. Melesatkan Prestasi Akademik Siswa. Cet. 1; Yogyakarta: Pedagogia, 2010.

Naim, Ngainun. Menjadi Guru Inspiratif. Yogyakarta: Pustaka Pelajar, 2009.

Nasution S. Teknologi Pendidikan. Cet.4; Jakarta: PT Bumi Askara, 2008.

Nata, Abuddin. Perspektif Islam Tentang Strategi Pembelajaran. Cet. 3; Jakarta: Kencana, 2014.

Nurdin. (2014, 28-30 May 2014). Understanding government eprocurement effectiveness from users' perspectives: A case of social media discussion in Indonesia local government. Information and Communication Technology (ICoICT), 2014

Nurdin, N. (2017a). Research in Online Space: The Use of Social Media for Research Setting Jurnal Sistem Informasi (Journal of Information System), 13(1), 67-77.

Nurdin, N. (2017b). To Research Online or Not to Research Online: Using Internet-Based Research in Islamic Studies Context. Indonesian Journal of Islam and Muslim Societies, 7(1), 31-54.

${ }^{1}$ Nurdin, N. (2016). The Roles of Information Technology in Islamic Bank Knowledge Management: A study of Two Syariah Banks in Palu. Hunafa: Jurnal Studia Islamika, 13(2), 181217.
Peterson,Yan. Kamus Lengkap InggrisIndonesia, Indonesia-Inggris. Surabaya: Karya Agung, 2005.

Prawira, Purwa Atmaja. Psikologi Pendidikan Dalam Perspektif Baru.

Cet 1;Jogjakarta:Ar-Ruzz Media,2013.

Prawiradilaga, Dewi Salma. Wawasan Teknologi Pendidikan. Jakarta: Kencana Prenada Media Group, 2012.

Rohani, Ahmad. Media Instruksiaonal Edukatif. Jakarta: Rineka Cipta, 1997.

Ruslan, Rosady. Metode Penelitian Public Relation dan Komunikasi. Cet. IV; Jakarta: PT. Raja Grafindo Persada, 2004.

Rusman, Deni Kurniawan dan Cepi Riyana, Pembelajaran Berbasis Teknologi Informasi dan komunikasi. Cet. 3; Jakarta: PT Raja Grafindo Persada, 2013.

Rusman. Belajar dan Pembelajaran Berbasis Komputer. Bandung, Alfabeta, 2012.

Sadiman,Arief S. Media Pendidikan:Pengertian, Pengertian, dan Pemanfaatanya. Jakarta: PT Raja Grafindo Persada, 2007.

Sanjaya, Wina. Strategi Pembelajaran. Jakarta: Kencana, 2007.

Santrock, John W. Educational Psychology; Psikologi Pendidikan diterjemahkan oleh Tri Wibowo. Ed.2 Cet. 2; Jakarta: Kencana, 2008.

Silberman, Mel. Active Learning (101 Strategi Pembelajaran Aktif). Yogyakarta: Yappendis, 2002.

Sudjana, Nana, \& Ahmad Rivai, Teknologi Pengajaran. Jakarta: Sinar Baru Algensindo, 2003. 
Sugiyono, Metode Penelitian Pendidikan Pendekatan Kuantitatif, Kualitatif, dan RED, 194.

Sukadji, Psikologi Pendidikan dan Sekolah/Madrasah. Jakarta, Fakultas Psikologi Universitas Indonesia, 2000.

Sukiman. Pengembangan Media Pembelajaran. Yogyakarta: Pedagogia, 2012.

Suparman, M. Atwi. Desain Instruksional Modern; Panduan Para Pengajar dan Inovator Pendidikan. Jakarta: Erlangga, 2012.

Suryani, Nunuk. dan Leo Agung, Strategi Belajar Mengajar. Ombak;Anggota IKAPI, Yogyakarta, 2012.

Syahid, Ahmad. Rancangan Pembelajaran Model Elaborasi. Cet.2; Jember, Sains, 2008.

Tim Pengembang Kurikulum dan MKDP, Kurikulum dan Pembelajaran. Cet.4; Jakarta: Rajawali Pers, 2015.

Umar, Husein. Metode Penelitian untuk Skripsi dan Tasir Bisnis. Cet. IV; Jakarta: PT. Raja Grafindo, 2010.

Usman, Basyiruddin. dan Asnawir, Media Pembelajaran. Jakarta: Ciputat Press, 2002.

Widodo, Dkk. Kamus Ilmiah Populer Dilengkapi dengan EYD dan Pembentukan Istilah. Yogyakarta: Absolut, 2002.

Winarno Surakhmad, Dasar dan Teknik Research. Pengentar Metodologi Ilmiah. Bandung: Torsito, 2000.

W.J.S, Poerwadarminta. Kamus Umum Bahasa Indonesia. Jakarta: Gramedia, 1990.

Zainal, Veithzal Rivai, Dkk. Islamic Quality Education Management.
Cet.1; Jakarta: Gramedia Pustaka Utama, 2016. 